\title{
RESEARCH BRIEFS
}

\section{Private sponsorship in refugee admission: Standard in Canada, trend in Germany?}

Vanessa Pohlmann \& Helge Schwiertz Research Brief No. 2020/1

July 2020

The Research Briefs Series is produced jointly by the Ryerson Centre for Immigration and Settlement (RCIS) and the CERC in Migration and Integration www.ryerson.ca/cerc-migration 


\title{
Research Brief
}

No. $2020 / 1$

\section{Private sponsorship in refugee admission: Standard in Canada, trend in Germany?}

\author{
Vanessa Pohlmann \\ Institute for Migration Research and Intercultural Studies (IMIS) \\ University of Osnabrück \\ Helge Schwiertz \\ Institute for Migration Research and Intercultural Studies (IMIS) \\ University of Osnabrück
}

Series Editors: Usha George \& Anna Triandafyllidou

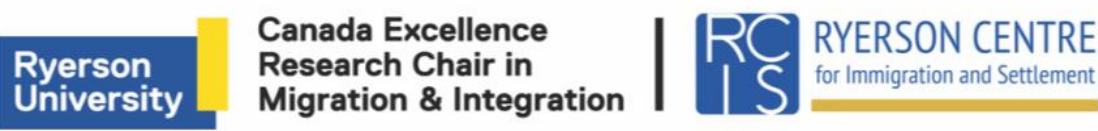

The Research Briefs Series is produced jointly by the Ryerson Centre for Immigration and Settlement (RCIS) and the CERC in Migration and Integration at Ryerson University.

Research Briefs are short, peer-reviewed commentaries of 2,000 to 4,000 words on pertinent and/or contemporary issues related to immigration and settlement. The views expressed by the author(s) do not necessarily reflect those of the RCIS or the CERC in Migration and Integration.

For further information, visit www.ryerson.ca/centre-for-immigration-and-settlement and www.ryerson.ca/cerc-migration.

ISSN: $1929-9915$

(i) $(9)$ Creative Commons Attribution-Noncommercial-No Derivative Works 2.5 Canada License 


\section{Introduction}

In Germany, a new program for refugee resettlement with the involvement of private actors is currently being tested.1,2 The controversially discussed pilot project points to a trend towards privatizing refugee reception policies - a model that was established in Canada more than 40 years ago and is a central pillar of its refugee policy. In this article, we compare programs of public-private cooperation in Germany and Canada and examine the relationship between the state and civil society with regard to these active refugee reception policies: In what ways is private sponsorship taking on tasks in the field of refugee policy that generally fall within the scope of state responsibility? And can the Canadian model be a prototype for German refugee policies?

\section{Refugee resettlement in Germany}

Private sponsorship is a special form of refugee resettlement organized in cooperation with the UN Refugee Agency (UNHCR). Current UNHCR numbers suggest that Germany is among the top five destinations for resettlement worldwide with around 4,600 departures in 2019 (non-UNHCR programs not included) - in Europe it is only outnumbered by Sweden and the U.K. The German humanitarian admission programmes have a history leading back to 1956. However, considering the quotas, resettlement plays quite a minor role compared to the number of refugees who go through the asylum system which is a complex institution with legislation distinguishing between various types of protection offered to persons in need of international protection. The 4,600 resettled refugees contrast with approximately 142,509 first-time applications for asylum in the same year. Legally, there are also some slight differences in the residence status between a resettled refugee, a convention refugee and a person granted asylum.

Private sponsorship is an even more special case in the German context, where the first programme designated as such was only launched in 2019. What generally distinguishes private sponsorship from other resettlement forms is the comprehensive social, emotional and financial support of refugees by individuals, groups or organisations from civil society. The timeframe for support is usually defined in advance and is often one year, sometimes longer (Kumin, 2015). The privately sponsored programs are to be run as an alternative to and in a complementary manner to the state-financed resettlement programs with the goal of increasing the total quota of reception (European Migration Network, 2016).

1 This is a revised version of a German-language article that was published on 01.10.2019 on the FluchtforschungsBlog. We would like to thank Marcus Engler and the anonymous reviewer of the $\mathrm{RCIS}$ for their helpful comments. The article is part of the research project "From Refugee Support to Escape Aid. Refugee Protection as a Conflicting Issue in the German Migration Regime and the Role of Civil Society Initiatives" (Schwiertz \& Schwenken, 2020; Schwiertz \& Steinhilper, 2020). 2 As of July 2020, all private sponsorship programs are paused due to COVID-19. In March 2020, UNHCR and IOM had announced that all resettlement measures would be temporarily suspended due to COVID-19 travel restrictions. As a result, the Canadian as well as German programmes described in this article are currently on hold for an uncertain period of time with only very few exceptions. For a more detailed overview of the COVID-19 resettlement suspension see https://blog.fluchtforschung.net/the-covid-19-resettlement-suspension/. 


\section{Neustart im Team ["New start in a team"]}

In November 2019, the first refugees landed in Germany via the new private sponsorship program called "NesT - Neustart im Team." In May of the same year, the German Federal Government had launched the pilot project in which citizens play a leading role in the admission of refugees. They will be part of providing a safe haven for those seeking protection, provided that they commit themselves to supporting the refugees financially for two years as well as through volunteering.

\section{Precursors of the private sponsorship program}

\section{Länder admission programs and civil society engagement for refugees}

Although not common, there have already been some forms of de facto private sponsorship in Germany. The most notable are the Länder [federal states] admission programs established in 2013 which enable (primarily) Syrian refugees to bring their family members to the state they are residing in (European Commission, 2018). Such programs have been running in all federal states except Bavaria (Baraulina et al., 2016). They are currently still active in Berlin, Brandenburg, Hamburg, Thuringia, and Schleswig-Holstein. More than 23,000 visas were issued on this basis by the end of March 2018 (European Commission, 2018).

The requirement for the visa and the granting of a 2-year residence permit (according to $\S 23$ Abs. 1 AufenthG [Residence Act]) is that a private person assures - by signing a socalled declaration of commitment - to bear all costs of living of the persons and families to be resettled. Healthcare is exempted and will continue to be borne by the states (European Commission, 2018; European Resettlement Network, 2017). Initially, sponsors had to act as a guarantor for the refugee for an unlimited period of time. This financial obligation was only limited to five years in August 2016, when the Integration Act came into force (Baraulina et al., 2016).

In addition to these official programs, volunteer initiatives for refugee assistance, particularly from 2015 onwards, have taken on comprehensive tasks in the reception and support of refugees, which normally fall within the remit of the state: according to international and European law, Germany is obliged to grant protection to recognized refugees, and the principle of the welfare state prescribes the provision of a humane minimum subsistence level for all individuals, as the Federal Constitutional Court explained in a ruling of 2012. In the context of this broad movement of refugee support, initiatives have also emerged in the specific area of private sponsorship.

\section{The Syrian refugee sponsors}

To enable private individuals to undertake the immense responsibility of acting as a refugee's guarantor in the Länder programs, civil society stepped in and founded associations based on the idea of burden-sharing in Berlin, Hamburg and Thuringia. The Berlin based association Syrian Refugee Sponsors (German: "Flüchtlingspaten Syrien"), for example, has set up a sponsorship system. Through this system, sponsors are only formally committed but in practice do not have to bear the actual costs individually. Instead, the costs are taken over by a larger group of around 4,500 sponsors with the help of donations, so that the "risk weighs on many shoulders" (Interview Syrian Refugee Sponsors, 2018). Since its establishment in 2015, more than 200 refugees have been brought to Germany. 
The association has set up a comprehensive and professional support structure for the administration of family reunification and the integration of the host family members on site. This structure made the project appear as a government agency to many refugees. On the one hand, the association offers a comprehensive support program: welcome meetings, weekly consultation hours, events on topics like refugee law or job integration, language courses, parties and excursions, home visits and "family guides". On the other hand, they are working a "social benefit-like" concept in accordance with the standard rate of unemployment benefit, since the sponsors are responsible for covering their costs of living. In some cases, the Syrian Refugee Sponsors act similarly to a welfare authority. In this way the association tries to promote the refugees' integration "from the first day on" and to guide them to become "productive" and financially independent (Interview Syrian Refugee Sponsors, 2018), which would also reduce the association's expenses. The Syrian Refugee Sponsors project largely corresponds to the aims of the activating state: from welfare to workfare - those who make use of public or, in this case, private services should contribute something to society (Barbier \& Ludwig-Mayenhofer, 2004; Dingeldey, 2007). In the case of the Syrian Refugee Sponsors, the association's members, as active citizens, take on government tasks. In addition to that, they aim at activating the refugees themselves, similar to state authorities. But, different to the authorities, they hardly impose any sanctions on them.

The association itself views the involvement of civil society in Länder admission programs and its own role as quite ambivalent. On the one hand, it appreciates that the state is opening up this way of accepting refugees and making civil society engagement possible, which often has better ways of reacting to refugees' needs. On the other hand, the argument could be made that the program and the necessity of private initiatives are symptomatic of the failure of refugee policy and the shifting of state tasks to citizens. In any case, the German Federal Government has recognised the benefits of civil society involvement and, some 4 years after the founding of the Syrian Refugee Sponsors, has set up an official private sponsorship program.

\section{Neustart im Team ["New start in a team"] - Private sponsorship as a new model in Germany}

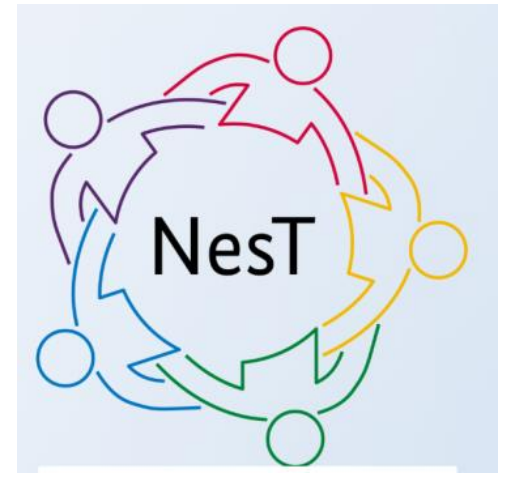

NesT (short for Neustart im Team) is the first nationwide private sponsorship program. It is a pilot project for up to 500 "particularly vulnerable refugees" who have already fled their home country and sought shelter in Ethiopia, Egypt, Jordan or Lebanon. Those refugees are to be admitted as part of the 2018-19 humanitarian admissions plan for Germany. The admission order states that they will be resettled to Germany within the framework of the resettlement procedure (§23 Para. 4 AufenthG [Residence Act]). There, they will be looked after by a group of mentors of at least five persons, similar to Canada's 'Groups of Five.' A matching procedure takes into account factors such as the family size, the available living space and possible special needs of those seeking protection. The mentor group in Germany then receives their profile and decides whether they want to support them, but a rejection of the proposed persons due to their profile is only permissible in special cases. With the declaration of support, the sponsors commit to provide appropriate housing, or pay for it, for a period of two years. In addition, they accompany the newcomers for at least one year, e.g. to visiting the authorities, in the search for schools, 
jobs or leisure activities. The newly established "Civic Contact Point" ("Zivilgesellschaftliche Kontaktstelle"), which consists of representatives of the German Caritas Association, the German Red Cross and the Protestant Church of Westphalia, supports the mentors through providing information on the project as well as trainings and advice.

Among actors of long-term refugee support, there have been ambivalent opinions regarding the concept of private sponsorship. Refugee councils - which have been established as independent associations of migrant and support groups at the state level in Germany from the 1980s onwards - are generally in favour of additional legal access routes through resettlement, sponsorship models and cooperation between the state and civil society in the reception of refugees. However, they criticize the participation of citizens in housing costs and, generally, the introduction of an elaborate new program. They argue that the quotas of the classic resettlement scheme, which is similar to NesT in many respects, could simply be extended. In addition, refugee councils complain that, in contrast to the usual practice of private sponsorship, the mentors do not have the right to name refugees to be resettled and are not involved in the selection. As a result, any form of family reunification via NesT is impossible.

The latest developments in the NesT program are the first arrivals under the mechanism with refugees being supported by mentor groups from Bavaria and NorthrhineWestfalia. As of December 2019, more than 30 mentor groups are interested in joining or have joined the pilot project. While private sponsorship is still in its infancy in Germany, there are decades of experience in Canada.

\section{Private sponsorship as a long-established institution in Canada}

In Canada, the private sponsorship program was introduced 40 years ago when some 21,000 refugees arrived from Indochina. This way, Canada became the first country in the world to bring to work such a model for refugee reception. It has long been an important part of Canada's reception policies, as the figures show.

In April 2019, the Canadian Federal Department of Immigration, Refugees and Citizenship Canada (IRCC) announced that more privately sponsored refugees would be welcomed to Canada in 2019: 19,000 refugees, an increase of 1,000 over the previous year. For the years 2020 and 2021, the numbers are increased again by 1,000 to the target of 20,000 privately sponsored resettled refugees for each year. In the Canadian system, private sponsorship is counted towards the total settlement quota. It is therefore questionable to what extent private sponsorship really creates additional admission places.

Sponsors are, in the Canadian case, organisations and groups of private individuals that can name who they wish to sponsor - unlike in the German pilot project. In the process they must take numerous guidelines into account. Resettled refugees in Canada will generally receive an unlimited permanent residence. Private sponsors are responsible for providing 12 months of income support plus start-up costs which together amount to an estimated total annual settlement cost of $\$ 16,500$ CAD (approx. 14,832 EUR) for housing, clothing and food for one person. Apart from that, sponsors have to support the sponsored person(s) in non-material ways, e.g. by helping them find a job.

While the Canadian system is often seen as a role model, various studies show its ambivalence. For example, private sponsorship can increase resettlement quotas (Lenard, 2016) and Canadians are provided with an institutional framework to advocate for refugee's and human rights (Krivenko, 2012). Furthermore, studies indicate that privately sponsored refugees integrate more quickly into the labour market compared to refugees receiving government support (e.g. Kaida et al., 2019). However, there are also fundamental concerns that private sponsorship, as a neo-liberal project, is attempting to privatize aid (Ritchie, 
2018). Further concerns relate to the dependency of the refugees on their sponsors and potentially paternalistic attitudes of the latter (Lenard, 2016). Apart from this, some see a "tug-of-war" between the conflicting interests of the sponsors and the government with regard to selection and admission numbers (Labman, 2016). The Canadian Refugee Council (CCR) and scholars (e.g. Krivenko, 2012) also criticize the elimination of the source country class (the direct transfer of people seeking protection from their country of origin to Canada). private sponsorship program had previously opened up an additional escape route in this regard. The changes to the program introduced in 2011 weaken the position of sponsors in the naming of persons (Hyndman et al., 2017) and a state-defined upper limit restricts the number of privately sponsored refugees. Further changes have led to restrictions on the selection criteria, additional bureaucracy, less support from government officials and very long waiting times, especially for refugees from Africa. Further scholars like Labman (2016) fear that private actors are under pressure and face the challenge of "doing more with less."

\section{The Canadian program - A model for Germany and other countries?}

What would it mean to establish private sponsorship as an integral part of German refugee policy? In order to implement a private sponsorship model as in Canada, a number of preconditions are required. First, civil society needs to be prepared to support refugees and mobilize private resources. This commitment has already been shown in the case of the Länder programs. Additionally, legal frameworks (such as § 23 Para. 4 AufenthG [Residence Act]) are required, on the basis of which the refugee can safely enter the country by visa and obtain a residence permit. To mediate between the state and the citizens and to support the latter, stable structures and institutions are needed, for example regulations for application, selection and matching processes as well as long-term advisory centres such as the Civic Contact Point.

Institutionalizing the program, as in Canada, would give public recognition to civil society's commitment to refugee reception. In addition, providing permanent residency from the outset would be required to give refugees a secure perspective regarding their future, which is currently not the case in Germany (resettled refugees receive a limited residence permit in accordance with $\S 23$ Para. 4 AufenthG [Residence Act] and can only obtain a settlement permit after three years). However, the Canadian implementation of private sponsorship also has problematic aspects. The increasingly restrictive regulations on the number and selection of refugees make the process complicated for potential sponsors and make access more difficult for those seeking protection. Long and varying processing times depending on the region of origin can lead to frustration for private actors and the feeling of loss of control in the private sponsorship process towards the government - despite high personal commitment.

In light of the Canadian experience, it is therefore important to make private sponsorship legally possible, easy to implement and accessible. Furthermore, the additionality of private sponsorship should be secured, even though it is questionable whether it is even still a feature in the Canadian policy: currently, it is almost two-thirds of resettled refugees who access Canada through private sponsorship and the government is including them in the overall 'Refugees and Protected Persons' quota of its 'Immigration Levels Plan'. So far, the new German program NesTs admission places have also been counted towards the total resettlement places, so that the criterion of additionality is not fulfilled here either. Scholars and organizations also advocate that sponsors should be able to name the refugees to be admitted without limits, which is also not the case with NesT. As CPJ highlights, personal connections to refugees in need often compel sponsors to commit 
to the financial undertaking and provide the settlement services. Sponsors often maintain close informal networks and connections to local people and are therefore able to learn directly about emergencies and react quickly (Krivenko, 2012). Therefore, naming can be seen as a major factor that drives sponsors in their wish to engage in refugee resettlement. However, there are also critical voices against naming: due to the high rejection rates in these cases, the attempt to name and resettle a refugee is often fruitless and resources are used for the procedure without success (Labman, 2016).

\section{Conclusion}

Overall, the introduction of private sponsorship programs in Germany appears to be an ambivalent project with its implementation remaining unclear. On the one hand, new possibilities of refugee admission are created, on the other hand, the total number of refugees admitted as a result has not yet been significantly increased and the outsourcing of protection to civil society can be accompanied by a precarisation of rights. In addition, the same aspect of limited impact regarding numbers applies to this model as to resettlement as a whole and other state-organized refugee reception policies. These currently only allow a small and selected group of refugees to seek shelter in countries of the Global North. It is therefore problematic if these policies are indirectly used to justify the criminalisation of undocumented flight movements. On the contrary, state reception of refugees should be accompanied in the long term by recognition of their self-determined mobility. Currently, it is not sponsors, or even nation states, but primarily the refugees themselves, who enable access to refugee protection, even if illegalized and often dangerous escape routes have to be taken due to the rigid border controls. 


\section{References}

Baraulina, T., Bitterwolf, M., \& Grote, J. (2016). Resettlement and Humanitiarian Admission Programs in Germany. Focus-Study by the German National Contact Point for the European Migration Network (EMN). Working Paper, 68, 1-72. Retrieved from https://ec.europa.eu/home-affairs/sites/homeaffairs/files/what-we-

do/networks/european_migration_network/reports/docs/emn-studies/emn-studies-

11 a germany resettlement humanitarian admission en.pdf

Barbier, J-C., \& Ludwig-Mayerhofer, W. (2004). Introduction. The many worlds of activation. European Societies 6(4), 423-36. doi:10.1080/146166904200027584.

Dingeldey, I. (2007), Between workfare and enablement - The different paths to transformation of the welfare state: A comparative analysis of activating labour market policies. European Journal of Political Research, 46(6), 823-851. doi:10.1111/j.1475-6765.2007.00712.x

European Commission. (2018). Study on the feasibility and added value of sponsorship schemes as a possible pathway to safe channels for admission to the EU, including resettlement. Final report - Study. Retrieved from

https://op.europa.eu/en/publication-detail/-/publication/1dbb0873-d349-11e8-942401aa75ed71a1/language-en/format-PDF/source-77978210

European Migration Network (EMN). (2016) Resettlement and Humanitarian Admission Programs in Europe - what works? Retrieved from https://www.refworld.org/docid/5a5f28fe4.html

European Resettlement Network. (2017). Private Sponsorship in Europe. Expanding complementary pathways for refugee resettlement, retrieved from:

https://www.icmc.net/sites/default/files/documents/scoping-paper-icmc-europe2017.pdf

Hyndman, J., Payne, W., \& Jimenez, S. (2017). Private refugee sponsorship in Canada. Forced Migration Review, 54, 56-59.

Kaida, L., Hou, F., \& Stick, M. (2019). The long-term economic integration of resettled refugees in Canada: a comparison of Privately Sponsored Refugees and Government-Assisted Refugees. Journal of Ethnic and Migration Studies, 45, 1-22.

Krivenko, E. (2012). Hospitality and Sovereignty: What Can We Learn from the Canadian Private Sponsorship of Refugees Program? International Journal of Refugee Law, 24(3), 579-602, https://doi.org/10.1093/ijl/ees039

Kumin, J. (2015). Welcoming engagement. How private sponsorship can strenghten refugee resettlement in the European Union. Migration Policy Institute. Retrieved from https://www.migrationpolicy.org/sites/default/files/publications/Asylum-

PrivateSponsorship-Kumin-FINAL.pdf

Labman, S. (2016). Private Sponsorship: Complementary or Conflicting Interests? Refuge, 32(2), 67-80. Retrieved from https://refuge.journals.yorku.ca/index.php/refuge/article/view/40266

Lenard, P. (2016). Resettling refugees: is private sponsorship a just way forward? Journal of Global Ethics, 12(3), 300-310. doi:10.1080/17449626.2016.1247290

Schwiertz, H., \& Steinhilper, E. (2020). Countering the Asylum Paradox through Strategic Humanitarianism. Evidence from Safe Passage Activism in Germany. Critical Sociology (online first). https://doi.org/10.1177/0896920520932215.

Schwiertz, H., \& Schwenken, H. (2020). Mobilizing for Safe Passages and Escape Aid: Challenging the 'Asylum Paradox' between Active and Activist Citizenship, Humanitarianism and Solidarity. Citizenship Studies 24(4), 493-511. https://doi.org/10.1080/13621025.2020.1755174. 